Marquette University

e-Publications@Marquette

Theology Faculty Research and Publications

Theology, Department of

4-1-2013

Against the Consensus of the Fathers? Isaiah 7:14 and the Travail of Eighteenth-Century Catholic Exegesis

Ulrich Lehner

Marquette University, ulrich.lehner@marquette.edu

Published version. Pro Ecclesia, Vol. 22, No. 2 (Spring 2013): 189-221. Publisher link. (C 2013 Center for Catholic and Evangelical Theology. Used with permission. 


\section{AGAINST THE CONSENSUS OF THE FATHERS? ISAIAH 7:14 AND THE TRAVAIL OF EIGHTEENTH- CENTURY CATHOLIC EXEGESIS}

\section{Ulrich L. Lehner}

In 1546, the fourth session of the Council of Trent passed the Decree on the Edition and the Use of the Sacred Books. The Council fathers regarded this to be a necessary response to the many translations and Scripture commentaries in circulation that, in their view, confused the faithful and could potentially draw them to Protestantism. In order to ensure that the faithful would use only proper commentaries or translations, certain rules for official publication permissions were implemented. More importantly, this decree stated a hermeneutic principle for all Catholic theologians, in particular for exegetes. This principle affirmed the continuity of teaching of faith and morals between the church of old and the church of the Tridentine reform, and admonished consistency with the Fathers of the church. The decree read,

In order to restrain petulant spirits, [the Council] decrees, that no one, relying on his own skill, shall, -in matters of faith, and of morals pertaining to the edification of Christian doctrine,-wresting the sacred Scripture to his own senses, presume to interpret the said sacred Scripture contrary to that sense which holy mother Church,-whose it is to judge of the true sense and interpretation of the holy Scriptures, - hath held and doth hold; or even contrary to the unanimous consent of the Fathers; even though such interpretations were never (intended) to be at any time published.

Ulrich L. Lehner, Associate Professor of Historical Theology, Marquette University, PO Box 1881, Milwaukee, WI 53201. E-mail: ulrich.lehner@ marquette.edu 
Contraveners shall be made known by their Ordinaries, and be punished with the penalties by law established. ${ }^{1}$

In the eighteenth century, in the midst of the rise of historical criticism, the question was discussed anew as to what extent a Scripture scholar must follow the Fathers. The case of Johann L. Isenbiehl, who not only lost his university chair in exegesis in Mainz, but also was imprisoned for going against the consensus of the Fathers, exemplifies this theological discussion. Isenbiehl had claimed to have explored a literal or historical interpretation of Isa 7: 14 that made the traditional typological or allegorical interpretation of the verse redundant. In the following paragraphs I will first reconstruct the place of literal meaning for post-Tridentine Catholic exegesis, and then discuss eighteenth-century concepts of theological freedom in interpreting Scripture. This contextualization suggests Isenbiehl emerging as a theologian who went beyond Muratori's concept of theological freedom, thus advancing Catholic Enlightenment, relying on the tools of historical criticism alone while bracketing tradition. Consequently, it will become clear that Isenbiehl's censoring did not happen because he used a literal interpretation or Michaelis's historical-critical method but because he rejected the consensus of the Fathers and tradition. As such his case is exemplary to demonstrate the complex methodological and theological issues Catholic exegesis had faced between 1750 and 1800 .

\section{LOSING AND FINDING THE LITERAL MEANING OF SCRIPTURE}

The medieval commentaries on Scripture usually based their mystical interpretations, whether allegorical or typological, on a careful reading of the literal meaning of the text. ${ }^{2}$ During the sixteenth century, this emphasis on the literal meaning was still very much adhered to by Catholic exegetes in their often remarkable commentaries (e.g., Maldonatus). Over the course of the seventeenth century, however, literal emphasis had steadily declined, and thus it was fitting that the ingenious French

1. "Decretum de editione et usu sacrorum librorum," according to the translation of James Waterworth, Canons and Decrees of the Council of Trent (London: C. Dolman, 1848), 19-20. For the original Latin see Heinrich Denzinger and Peter Hünermann, eds., Enchiridion symbolorum: A Compendium of Creeds, Definitions, and Declarations of the Catholic Church (San Francisco: Ignatius Press, 2012), DH 1507.

2. Literature on medieval exegesis and its respect for literal interpretation is legion. One can begin by consulting Jane Dammen McAuliffe et al., eds., With Reverence for the Word: Medieval Scriptural Exegesis in Judaism, Christianity, and Islam (Oxford: Oxford University Press, 2003), as well as Alan Hauser et al., eds., A History of Biblical Interpretation, vol. 2 (Grand Rapids: Eerdmans, 2003). 
Oratorian Richard Simon (1638-1712) attempted to recover it with modern philological tools. His attempts, however, were associated with Spinozism and consequently were mostly ignored by his Catholic peers. ${ }^{3}$ Simon's confrere, the Oratorian Bernard Lamy (1640-1715), even stated in his Apparatus Biblicus (1696) that the Church Fathers had neglected, not ignored, the literal sense because it was their motivation to mold the faithful into saints, not scholars (non doctiores ... sanctiores). ${ }^{4}$ Despite these singular efforts to reemphasize the importance of the literal meaning of the Bible, exegesis in Catholic universities continued to decline markedly in favor of controversial and polemical theology for yet another generation. The fear that an emphasis on the literal meaning of the text would indirectly help Protestant causes was too great. ${ }^{5}$ Apart from quarrels with Protestantism, the controversies with Jansenism also affected the place of Scripture in Catholic theology. Against the Jansenists, the bull Unigenitus (1713) condemned the proposition that the reading of the Bible was necessary for everyone's salvation. This, however, could be interpreted as a new Catholic marginalization of Scripture. The Reform Benedictines of St. Maur desired to refute such allegations and supported their member Augustine Calmet O.S.B. (1672-1757), as well as his disciples, in demonstrating the centrality of Scripture for the Catholic faith. Calmet reemphasized the literal meaning of the text. His monumental "literal" commentary on all books of the Old and New Testament energized many to delve into Scripture, and it became one of the most widely read commentaries in the Catholic world. ${ }^{6}$ From the middle of the eighteenth century onward, there was an explosion of interest among Catholics in oriental languages, biblical archaeology, and exegesis, in which Calmet had played an enormous role.

3. See Sascha Müller, Kritik und Theologie: Christliche Glaubens- und Schrifthermeneutik nach Richard Simon (1638-1712) (St. Ottilien: EOS, 2004).

4. Bernard Lamy, Apparatus biblicus: nova editio (Lyon: 1696), lib. II, ch. 8, 395.

5. For a contemporary's view, see Gallus Cartier O.S.B. († 1777) of Ettenheimmünster, Tractatus theologicus de sacra scriptura (Freiburg: 1736), praefatio: "Deplorandam sane nonnullorum nostri aevi Theologorum indolem, qui neglecto hoc tam salubri \& firmandae nostrae Religioni adeo necessario sacrae Scripturae studio, utpote unde potissimum solida argumenta nostrae fidei eruuntur, rerum non adeo utilium sectantur cognitionem." See also Sebastian Merkle, Die kirchliche Aufklärung im katholischen Deutschland (Berlin: Reichl, 1910) 74-75; F. J. Crehan, "The Bible in the Roman Catholic Church from Trent to the Present Day," in Cambridge History of the Bible, vol. 3 (Cambridge: Cambridge University Press, 1963), 199-237; Richard H. Popkin, The Third Force in Seventeenth-Century Thought (Boston: Brill, 1992), 30-32.

6. Augustin Calmet, Commentaire litteral sur tous les livres de l'Ancien et du Nouveau Testament (Paris: 1724-1726).

7. See Marius Reiser, "Catholic Exegesis between 1550 and 1800," in Ulrich L. Lehner, Richard Muller, and A. G. Roeber, eds., The Oxford Handbook of Early Modern Theology (Oxford: Oxford University Press, forthcoming). 
The work of the Maurists, and in particular Calmet's work, was the result of a successful implementation of the Tridentine Reforms and its rediscovery of Scripture as the source of ecclesial life. ${ }^{8}$ The other important reason for this revival was, however, the lively discourse with the Enlightenment in which Simon, Lamy, Calmet, and others engaged. While the first cautious exchanges with Enlightenment criticism had been on historiographical issues, soon this engagement began also to spread to other disciplines of theology. Open-minded theology departments, religious orders, bishops, and rulers throughout Europe attempted to implement such a dialogue with the spirit of the times and supported the renewal of Catholic exegesis. ${ }^{9}$ While most Catholic exegetes merely reemphasized the literal meaning-or historical meaning, as it now increasingly was called-and more clearly reestablished it as the basis for any further mystical interpretation, a few desired to minimize mystical interpretations as a whole. ${ }^{10}$

By stressing the literal meaning of the text and using the tools of textual criticism, however, one could arrive at interpretations that would contradict the consensus of the Fathers. This was a serious theological conundrum. In swift succession, the Protestant world of scholarship presented Catholics with a number of new challenges. Many Protestant scholars claimed that hitherto obscure scriptural passages could now be interpreted literally, which would render mystical interpretations at least questionable. At the same time, others confronted their Catholic peers with the uncomfortable reality that even the consensus of the Fathers had erred in some biblical interpretations. Catholic theologians therefore pondered how to resolve this problem while nevertheless remaining faithful to the decrees of the Council of Trent. Catholic Enlighteners did not view Trent's decision as an impediment for research, but rather attempted to develop a hermeneutic of continuity that allowed them to follow both the Council and the findings of their research. Nonetheless, there seemed to be boundaries that no theologian was supposed to cross.

8. See Louis Châtellier, The Religion of the Poor: Rural Missions in Europe and the Formation of Modern Catholicism, c.1500-c.1800 (Cambridge: Cambridge University Press, 1997); and Guy Bedouelle, The Reform of Catholicism, 1480-1620 (Toronto: Pontifical Institute of Mediaeval Studies, 2008).

9. Calmet knew the achievements of modern archaeology and criticism, but he was not a critically minded exegete, as Bertram Schwarzbach suggests in "Dom Augustin Calmet: Man of the Enlightenment despite Himself," Archiv für Religionsgeschichte 3 (2001): 135-48.

10. See the general remarks of Benedict Stattler, De locis theologicis (Ingolstadt: 1777), 110: "Sensus mysticus nunquam sine literali bene tamen literalis sine mystico esse potest. ... Sensus mysticus in literali fundari debet, id est, inesse rebus sensu literali expressis, ceu signis suis." See the insightful reflections of Benedict Werkmeister, "Ueber den mystischen Sinn," Jahrschrift für Theologie und Kirchenrecht der Katholiken 2 (1809): 259-376. 


\section{MURATORI AND THE MODERATE FREEDOM OF THE EXEGETE}

It is the great achievement of Ludovico Muratori (1672-1750), the friend of Pope Benedict XIV (1740-1758), to have outlined those boundaries. In his On the Moderation of Our Cleverness in Religious Matters (1714), he painted a picture of how far a theologian's freedom in academic research could go, and where he had to be obedient to tradition and church rulings. This inspired generations of eighteenth- and nineteenth-century Catholic theologians to engage with modern thought and culture, although the limitations Muratori envisioned would soon be regarded as too narrow. ${ }^{11}$ Muratori was unhappy about the state of Catholic exegesis, but instead of simply arguing in favor of the superiority of the literal meaning of the text, he distinguished that every literal meaning of Scripture was either proper [proprium] or figurative [figuratum]. While his theological hero St. Augustine had defended the view that a passage could have several literal meanings, others denied this. Muratori therefore attempted a reconciliation of both positions.

One has to suppose then that the Holy Spirit wanted/intended [voluisse] to express one literal sense (not excluding the mystical one), either in proper or figurative words. Because the words of Scripture can sometimes be obscure [obscura] as to their literal meaning, and can be interpreted in various ways, it is often not certain whether one should understand it properly or figuratively: therefore it is licit to apply to such a passage different literal interpretations. ${ }^{12}$

In order to give the theologian as much freedom as possible and to guarantee that he would not be slandered as a heretic if he applied such a different explanation, Muratori insisted that "every one of these [interpretations] - as long as it does not violently contort Scripture, and does not contradict Scripture, tradition or reason in other aspects-can be regarded as suitable [convenire], can be laudable [laudari] and permissible [tolerari]." Any interpretation could be used because the one and only literal meaning the Holy Spirit intended was not evident [evidenter]. Such liberality in interpretation, however, was not licit for passages where such meaning was evident or pertained to faith and morals. For these "can have only one literal meaning and explication rather than many, because the Church transmits the one and only intended full [germanum] meaning God has put in such a pasage," because the Church received such

11. Ludovico Muratori, De ingeniorum moderatione in religionis negotio [1714] (Augsburg: 1779). There is no English biography of Muratori available; however, Paola Vismara, "Ludovico Muratori," in Ulrich Lehner and Jeffrey Burson, Enlightenment in Catholic Europe: A Transnational History (Notre Dame, IN: University of Notre Dame Press, forthcoming) will provide a starting point with a useful bibliography.

12. Muratori, De ingeniorum moderatione in religionis negotio, lib. I, ch. 22, 231. 
meaning through divine instruction, tradition, and the unanimous consensus of the Fathers.

Therefore it is forbidden to deviate in the interpretation of such passages from the Church and the tradition of the Fathers. In other scriptural passages, however, where no salvific doctrine is entailed, and where the meaning is not certain, or where it is obscure and where a diverse literal interpretation seems convenient [commode], the opinion of St. Augustine and others is correct: Such a passage allows several different literal interpretations, which one can and must tolerate [posse ac tolerari debere]. ${ }^{13}$

For Muratori it was clear that Trent had decreed a nonnegotiable principle of theology, namely that of a continous teaching tradition, but that its terminology and implications had to be interpreted. The scholar from Modena decided to interpret Trent's decree in favor of the largest possible freedom for the theologian. This was a direct rejection of a narrow understanding of the Tridentine rule, which argued that in all biblical questions the consensus of the Fathers had to be followed. If one followed such an inflexible traditionalism, Muratori stated, the church could not participate in any fruitful dialogue with science, history, philosophy, or philology. In physics, Catholic teaching would be rendered irreconcilable with Copernicus, ${ }^{14}$ and any meaningful advances in biblical scholarship would be made impossible. Muratori instead argued that Trent did not disallow or anathematize historical, mathematical, astronomical, philosophical, or other investigations, whose results deviated from the Fathers, but that it admonished scholars to receive their authoritative words in humility and obedience if (and only if) they pertained to faith and morals. Consequently, the Council did not so much tame the "boldness" of creative intellects, but restricted the excessive zeal [zelum exuberantem] of those who abused the authority of the Fathers for inopportune [importune] teachings or explanations that did not "belong to the edification of Christian doctrine" [aedificationem Doctrinae]. ${ }^{15}$ Trent's decree was therefore in Muratori's opinion no straitjacket for the freedom of the theologian, but a protection against narrow-minded traditionalists.

Thus the Council Fathers have embraced most wisely the principle through which the unity of faith is maintained and the freedom of genius [ingeniorum libertatem] is not diminished. For they realized well that as long the veracity of Scripture and the doctrine of the true faith were ascertained ... one was not allowed to denounce [litem intendere $]^{16}$ the diverse

13. Muratori, De ingeniorum moderatione in religionis negotio, lib. I, ch. 22, 231.

14. Muratori, De ingeniorum moderatione in religionis negotio, lib. I, ch. $23,237$.

15. Muratori, De ingeniorum moderatione in religionis negotio, lib. I, ch. 23, 238.

16. Literally "to charge with a crime." 
opinions of interpreters in things that do not pertain to faith and morals and to the edification of Christian doctrine. ${ }^{17}$

For this Muratori relied on Francois Veron S.J. (1578-1649) and his De regula fidei catholicae (1645). According to Veron, one did not have to accept the motives and proofs behind the consensus of the Fathers and definite teachings of the Church, and one could consequently deviate from patristic commentaries. ${ }^{18}$ In reflections on the methodology of exegesis, the Augustinian exegete Alois Sandbichler of Salzburg (1751-1820) expressed agreement with Veron. ${ }^{19}$ Both Veron's and Muratori's viewpoints were discussed in eighteenth-century textbooks as the "recent" view [recentior] and were contrasted with the old one, which was called traditionalist, although there were certainly variations. ${ }^{20}$

As a characteristic proponent of the latter view, one could arguably name the ex-Jesuit Hermann Goldhagen (1718-1794), who also was the fiercest critic of Isenbiehl. In his many publications, a positive word about contemporary biblical scholarship is difficult to find, especially not in reference to Protestants. Goldhagen differed from the Carmelite Thaddaeus Dereser (1757-1827) and other enlightened German Catholic exegetes, not in the opinion that the three dimensions of a mystical interpretation (allegorical, analogical, tropological) were as important as the knowledge of the literal or historical meaning of a text, but in his unwillingness to admit that a number of traditionally mystically explained verses have only a literal meaning and therefore to concede mistakes of the Fathers. Moreover, Goldhagen differed from Dereser in his reluctance to concede that theologians, with the help of mystical interpretations, read dogmatic ideas into the text that the literal meaning could not justify. ${ }^{21}$ Against Aquinas, Goldhagen was even convinced that the mystical interpretation could be used for a dogmatic proof. ${ }^{22}$ In Goldhagen's eyes, scholars who so much as questioned whether a text could have several meanings or a possible mystical reading were Socinians ${ }^{23}$ or Crypto-Protestants,

17. Muratori, De ingeniorum moderatione in religionis negotio, lib. I, ch. 23, 238.

18. Francois Veron (1578-1649), De regula fidei Catholicae [orig.: 1645] (Valentia: 1801), c. 1, p. 4, nr. 5, 22: "Unde generaliter dicimus, eorum quae continentur in capitibus, id solum et totum esse de Fide, quod definitur, seu (ut loquuntur luristae) solum dispositivum arresti seu conteni in capite aut canone de Fide, motivum vero arresti, seu eius probationes, non sunt de Fide. Ratio est, quia primum solum proponitur credendum, et proprie definitur, non autem motivum seu probationem."

19. Aloys Sandbichler, Abhandlung über die zweckmässigen Mittel den hebräischen und griechischen Grundtext dem Wortsinne nach richtig zu verstehen (Salzburg: 1791), 556.

20. See Thaddaeus Dereser O.C.D., one of the most important Catholic German exegetes of the eighteenth century, in his Notiones generales hermeneuticae sacrae veteris testamenti (Bonn: 1784), 17.

21. Hermann Goldhagen, Introductio in Sacram scripturam veteris ac Novi Testamenti, vol. 1 (Mainz: 1765), 148-50; see for example Dereser, Notiones generales hermeneuticae, 18.

22. Goldhagen, Introductio, 157-58. Cf. STh I, q. 1, art. 10.

23. Goldhagen, Introductio, 157-58. 
because their emphasis on the literal text, the concepts the human author used, and their historical context echoed Protestant writers like Siegmund Jakob Baumgarten (1706-1757) ${ }^{24}$ and Georg Lorenz Bauer (1755-1806). ${ }^{25}$

\section{JOHANN DAVID MICHAELIS'S HOPE FOR CATHOLIC EXEGESIS: JOHANN L. ISENBIEHL}

One exegete in particular embodies the strife between these conflicting interpretations of Trent regarding agreement with the Fathers, namely Johann Lorenz Isenbiehl (1744-1818). While the Catholic Church chastised Isenbiehl, Protestant exegetes received his ideas with enthusiasm. Wilhelm Gesenius's (1786-1842) commentary on Isaiah, published in 1823, which marked the beginning of modern historical scholarship on this biblical book, stated that Isenbiehl had been the first exegete to defend in a sophisticated work the historical meaning of Isa 7:14, independent of any connection to the New Testament. ${ }^{26}$

When Isenbiehl accepted a chair as professor for exegesis at Mainz in 1773 - one of the most tolerant Catholic states in the Holy Roman Empire-his friend Johann Gertz (1744-1824) reminded him that a Catholic principality might not be prepared to accept the historical-critical method that had been victorious in Protestant theology: "Mainz is not Göttingen." ${ }^{27}$ Lorenz Isenbiehl, however, was naive enough to expect the small, hitherto Jesuit University of Mainz to become within weeks of his arrival as open-minded as his alma mater Göttingen. ${ }^{28}$

24. Sigmund Jacob Baumgarten, Unterricht von Auslegung der heil. Schrift (Halle: 1759), $55-87$.

25. Georg Lorenz Bauer, Entwurf einer Hermeneutik des Alten und Neuen Testaments (Leipzig: 1799), 96.

26. Wilhelm Gesenius, Philologisch-kritischer und historischer Commentar über den Jesaja I (Leipzig: 1821), 309-10. I am indebted in my interpretation to Marius Reiser, Bibelkritik und Auslegung der Heiligen Schrift (Tübingen: Mohr Siebeck, 2007), 277-328. Still very helpful in understanding the history of the interpretation of Isa 7:14 is Laurenz Reinke's Die Weissagung von der Jungfrau und vom Immanuel Jes. 7,14-16. Eine exegetisch-histoische Untersuchung (Munster: 1848).

27. On Gertz see Franz Rudolf Reichert, "Johann Gertz (1744-1824). Ein katholischer Bibelwissenschaftler der Aufklärungszeit im Spiegel seiner Bibliothek," Archiv für Mittelrheinische Kirchengeschichte 18 (1966), 41-99. For an overview of Isenbiehl's time in the theology department in Mainz, see Philipp Anton Brück, Die Mainzer theologische Fakultät im 18. Jahrhundert (Wiesbaden: F. Steiner, 1955), 41-59.

28. Sascha Weber, "Mainz ist nicht Göttingen. Der Mainzer Kurstaat und die Affäre Isenbiehl (1773-1780)," Archiv für Mittelrheinische Kirchengeschichte 61 (2009): 211-28; Norbert Jung, Der Speyerer Weihbischof Andreas Seelmann (1732-1789) (Mainz: Selbstverlag der Gesellschaft für Mittelrheinische Kirchengeschichte, 2002), 22-26, 624-61; Reiser, Bibelkritik, 277-330; Franz Rudolf Reichert, "Trier und seine Theologische Fakultät im Isenbiehlschen Streit (1773-1779)," in Georg Droege et al., eds., Verführung zur Geschichte. Festschrift zum 500. Jahrestag der Eröffnung einer Universität in Trier (Trier: NCO-Verlag, 1973), 276-301. 
Isenbiehl was born in 1744, undertook studies in the seminary in Mainz, and was ordained a priest in 1769. Almost immediately, he was sent as missionarius to the small Catholic parish of Göttingen, where he was allowed to continue his studies. Under the direction of Johann David Michaelis (1717-1791), one of the fathers of modern orientalism, Isenbiehl studied oriental languages and exegesis. ${ }^{29}$ It was here that Isenbiehl learned to read the Bible according to the historical-critical method. Michaelis vehemently rejected mystical interpretations, and Isenbiehl adopted his master's teaching that every type and image in a biblical text can have only one meaning, because otherwise it would be impossible to explain such an image with certainty. ${ }^{30}$ It must be noted that Michaelis did not dismiss the possibility of a double meaning of a verse, but he reserved those for idioms or mysteries. One could not, he argued, accept a double meaning without necessity. ${ }^{31}$ Michaelis liked his disciple, as is evident in a review of Isenbiehl's first publication about the Syrian diacritical point for verbs. The young priest had been so enchanted with exegesis, particularly with Syriac studies, that he wished to bring the riches of the Syriac tradition back into the bosom of the church. Michaelis, not a man whose praise one could easily win, commended Isenbiehl's zeal for studying oriental languages and his boldness in investigating a new theme. The idea of studying the diacritical points came to Isenbiehl in the summer of 1772, when he attended a seminar by Michaelis on Dathe's new Syriac Psalter..$^{32}$ Michaelis had high expectations of his Catholic master student: "A Catholic who focuses on Syriac can have some advantages over a Protestant. It will be much easier for him to visit Rome, and to improve his knowledge by studying the inexhaustable treasures of the Vatican Library and by conversing with Syrians. For the sake of the improvement of academic scholarship I hope that Mr. Isenbiehl will be able to enjoy such advantages." To the professor in Göttingen, Isenbiehl was a "lucky genius," who could "import the German way of thinking to Rome," and "of whom one can expect much."

After the suppression of the Society of Jesus, the University of Mainz discharged all but one Jesuit from professorial duties. With Isenbiehl, the university wanted to bring the newest, most current method of exegesis

29. For a recent study of Michaelis's methodology, see Michael C. Legaspi, The Death of Scripture and the Rise of Biblical Studies (Oxford: Oxford University Press, 2010).

30. Johann David Michaelis, Entwurf der typischen Gottesgelahrtheit (Göttingen: 2nd ed., 1766), 45. Cf. Michaelis, Entwurf, 47: "Um dieser Ursachen willen kann ich auch denen nicht beytreten, die beynahe in einem jeden Vorbilde erstlich das Geheimnis Christi und denn das Geheimnis der Kirche suchen."

31. Michaelis, Entwurf, 46-51.

32. Johann August Dathe, Psalterium Syriacum (Halle: 1768).

33. Johann Lorenz Isenbiehl, Beobachtungen von dem Gebrauche des syrischen Punkti diacritici bey den Verbis (Göttingen: 1773). Johann David Michaelis, Orientalische und Exegetische Bibliothek 4 (Göttingen: 1773), 45-52, at 47-48. A similar version of this review was also published in Göttingische Anzeigen von gelehrten Sachen 1 (1773): 185-86. 
to Mainz. On 26 November 1773 Isenbiehl informed his former teacher Michaelis that he had begun a lecture cycle on the Hebrew Bible, which had about thirty students, ten of whom were members of religious orders. Until then, in Mainz there had been "not only no desire to study Hebrew, but also no desire for erudition." ${ }^{\prime 34}$ Isenbiehl was expected to lecture on Syriac, Chaldean, Arabic, and Hebrew grammar. Since he embodied the critical method of Michaelis, even before his arrival a number of colleagues suspected him of being a heretic. Unfortunately, Isenbiehl did not pay much attention to the misgivings of his colleagues, believing that no one with reason and common sense could reject the Enlightenment. On 12 January 1774 he informed Michaelis that he had come up with a new explanation for Mt 1:22:

I cannot wait to communicate to you a new explanation of Mt 1:22. . . The words of Isaiah were quoted only ob analogiam signi prophetici... The Evangelist made this historic reflection, not in an historical style, but with the help of a biblical quotation. In the same way he described the distress of the mothers of Bethlehem with biblical words in chapter 2:17-18. . . I was already because of this explication regarded a half-heretic, and consequently forced to communicate my thoughts in print. ${ }^{35}$

Students had reported Isenbiehl's "suspicious" exegesis, because it shed doubt on whether Isa 7:14 was a prophecy about Christ's miraculous birth. Moreover, Isenbiehl's decision to defend himself in print was probably not the wisest, because his 140 theses about the Gospel of Matthew (April 1774) did not pass censorship. He was now officially under investigation for heresy. The archbishop elector continued to protect his exegete but would have preferred that he had taught the traditional allegorical or typological explanation of Scripture until the university reforms had been brought to a successful conclusion and the university had become part of the enlightened scientific community. ${ }^{36}$ For Isenbiehl, this would have been contrary to his conscience, and therefore, a drama was soon to unfold.

This drama began with the death of the Archbishop Elector BreidbachBüresheim in June 1774. Not even Karl von Dalberg (1744-1817), the

34. Staats- und Universitätsbibliothek Göttingen: $2^{\circ} \mathrm{Cod} \mathrm{ms}$ Michaelis 323 , fol. $424 \mathrm{v}$. I thank the SUB Göttingen for digitizing the correspondence between Isenbiehl and Michaelis for me, and Marquette University for generous funding.

35. Staats- und Universitätsbibliothek Göttingen: $2^{\circ} \mathrm{Cod} \mathrm{ms}$ Michaelis 323, fol. $425 \mathrm{f}$, Isenbiehl to Michaelis of 12 January 1774.

36. Brück, Die Mainzer theologische Fakultät, 46. Allegorical interpretation is the interpretative approach in which "biblical persons and incidents become representative of abstract virtues or doctrines," while a typological interpretation is the interpretation "whereby parts of the Hebrew Bible are read as foreshadowing and prediction of the events of the Gospels." James L. Kugel and Rowan A. Greer, Early Biblical Interpretation (Philadelphia: Westminster Press, 1986), 80-81. 
Mainz stadtholder of Erfurt, could protect Isenbiehl any longer. ${ }^{37}$ The conservative cathedral chapter took control of the diocese until the election of a new bishop and dismissed both Isenbiehl and two of his enlightened colleagues. The ex-Jesuit Hermann Goldhagen, who had made a name for himself not only as an exegete but especially as editor of an antiEnlightenment journal, was put in charge of hiring new professors for the university and the colleges of Mainz..$^{38}$ The new archbishop and elector, Friedrich Karl Erthal (1719-1802), did not return to the Enlightenmentfriendly politics of his predecessor, because he had promised the Cathedral chapter to hire only conservative teachers. ${ }^{39}$ At this point, Isenbiehl was punished for his exegetical teachings with a two year reeducation in the seminary of Mainz, where he was expected to learn the "orthodox interpretation of Scripture." Isenbiehl's career was over-before it had really begun. His bishop would not grant him leave to teach in the universalist Philanthropinum in Dessau, and no other theology department in the Reich dared to hire him. ${ }^{40}$

When Isenbiehl informed his teacher Michaelis about his dismissal on 1 November 1774, he stated that he was content with studying in the seminary but was most upset about the loss of his salary. He hoped that the new book about Isa 7:14 he had finished on 24 October 1774, New Attempt about the Prophecy of Immanuel, would bring him some monetary help. ${ }^{41}$ He lamented not being able to travel to libraries or to visit other scholars, but he tried to be content: "In the meantime I want to enjoy the grace of the Elector; and if it becomes a punishment, I want to regard it as grace, and keep working secretly." 42 He had to learn to regard the treatment of the elector as a grace sooner than he probably anticipated, because the archbishop elector-unbeknownst to Isenbiehl-had begun an official investigation of his writings on the suspicion of heresy. Even his letters were now censored or confiscated, so that he had to warn his teacher Michaelis to send the letters instead to a friend, "Mr. Trattenig, Bailiff of his Em. Count Metternich," who then smuggled them to Isenbiehl. ${ }^{43}$

37. For the interregnum see Heribert Raab, "Das Mainzer Interregnum von 1774," Archiv für Mittelrheinische Kirchengeschichte 14 (1962): 168-93.

38. On Goldhagen's journal see Franz Dumont, "Wider Freygeister, Protestanten und Glaubensfeger: Hermann Goldhagen und sein 'Religions-Journal,"' in Von 'Obscuranten' und Eudämonisten': Gagegenaufklärerische und antirevolutionäre Publizistik im späten 18. Jahrhundert, ed. Christoph Weiss (St. Ingbert: Röhrig, 1999), 35-76. For the life and works of Goldhagen see also Johannes Hompesch, Hermann Goldhagens Religionsjournal (PhD diss., Cologne, 1923).

39. Weber, "Mainz," 219; Raab, "Interregnum," 177-79.

40. Reichert, "Trier und seine theologische Fakultät," 281; Brück, Die Mainzer theologische Fakultät, 47. On the Philanthropin see Jörn Garber, Die Stammutter Aller Guten Schulen. Das Dessauer Philanthropinum und der Deutsche Philanthropismus 1774-1793 (Tübingen: Max Niemeyer Verlag, 2008).

41. Staats- und Universitätsbibliothek Göttingen: $2^{\circ} \mathrm{Cod}$ ms Michaelis 323, fol. 429.

42. Staats- und Universitätsbibliothek Göttingen: $2^{\circ} \mathrm{Cod} \mathrm{ms}$ Michaelis 323, fol. 429.

43. Staats- und Universitätsbibliothek Göttingen: $2^{\circ} \mathrm{Cod}$ ms Michaelis 323 , fol. 430. 
Michaelis must have written a touching account to his former student, because Isenbiehl responded on 28 December 1774 that he was moved to see how seriously and personally his teacher was taking the whole affair. Michaelis's letter was a sign to him of "sympathy and friendship." Isenbiehl advised him not to worry: "I am content and happy." ${ }^{44}$ His optimism made him believe that within two years he would teach again. He even made plans to engage with French scholars, for example, Paul Foucher (1704-1778) in Paris.5

The freedom from preparing lectures allowed Isenbiehl to concentrate on revisions and a substantial enlargement of the first draft of the New Attempt. The few people who saw the first draft of 1774 included, of course, Michaelis-but also the auxiliary bishop of Trier, Johann Nikolaus von Hontheim (1701-1790), who spearheaded the German Febronian movement; the exegete Gertz; auxiliary bishop Seelmann of Speyer (1731-1789); Abbot Rautenstrauch (1734-1785) of Vienna; and the enlightened theologian Franz Oberthür (1745-1851) of Würzburg. ${ }^{46}$ An informal inquiry as to whether the theology department of the University of Vienna would permit the printing of his book, was negative, despite the positive response of Rautenstrauch, its chairperson. The department called the book erroneous, false, and imprudent. In a letter to his teacher Michaelis on 15 May 1775, Isenbiehl complained: "I want to try one more time to get the book officially approved. If I do not receive permission, I want to publish the book without it. . . . Whoever reads my publications in the future will change his viewpoint, just as I converted all those who read my previous material." ${ }^{47}$ Only after repeated attempts to get the book past the censors failed, did Isenbiehl decide in 1777 to sell the manuscript and get it published without official permission. To publish a theological book without proper censorship approval was illicit, and such behavior of course caused a scandal. ${ }^{48}$ The proscription decree of the Elector of Mainz of 9 March 1778 emphasized that the book had not been approved by the censorship commission and contained "many" offensive and false propositions. ${ }^{49}$ It had been forbidden in order to protect the faithful from a book that mistreated Scripture and "deviated from its meaning as laid out by the Church Fathers." ${ }^{\prime 50}$ Trent's decree, which we

44. Staats- und Universitätsbibliothek Göttingen: $2^{\circ} \mathrm{Cod} \mathrm{ms}$ Michaelis 323, fol. 433.

45. Staats- und Universitätsbibliothek Göttingen: $2^{\circ} \mathrm{Cod} \mathrm{ms}$ Michaelis 323 , fol. 434-434v.

46. Isenbiehl sent these men his finished manuscript again in 1777. Their letters of approval are reprinted in Le Brets Magazin zum Gebrauch der Staaten- und Kirchengeschichte 7 (1783), 22-36.

47. Staats- und Universitätsbibliothek Göttingen: $2^{\circ} \mathrm{Cod} \mathrm{ms}$ Michaelis 323 , fol. $435 \mathrm{f}$.

48. The best exegetical analysis of the Isenbiehl controversy is Reiser, Bibelkritik, 277-330. It replaces the earlier account of Felice Montagnini, "L'interpretazione di Is 7, 14 die J. L. Isenbiehl," in Il messianismo: atti della XVIII Settimana biblica, ed. Alberto Vaccari and Augustin Bea (Brescia: Paideia, 1966), 95-105.

49. Religions-Journal 3 (1778), 192-96.

50. Religions-Journal 3 (1778), 196. 
discussed in the beginning of this article, had been invoked. The question of whether the interpretation of a verse was a truth of faith-because Isenbiehl never doubted the virgin birth or the Incarnation-was not asked by Isenbiehl's superiors, but only by his defenders. Within a year the book was proscribed, the author in jail, and within two years the papacy had officially condemned its exegesis for the entire church. ${ }^{51}$

\section{THE PROBLEM: VIRGIN OR YOUNG WOMAN?}

The seventh chapter of Isaiah recounts the so-called Syriac-Ephraimitic war. ${ }^{52}$ Around $734 \mathrm{BCE}$ the kings of Aram and Israel wanted to force Ahaz, the king of Judah, to join their coalition against the Assyrians. Isaiah met his king and offered him a guarantee of divine assistance, after Ahaz had refused the offer of a sign, "either in the depth, or in the height above" (Isa 7:11). The prophet admonished Ahaz not to weary God:

Therefore the Lord himself will give you this sign: the virgin (ha-almah) shall be with child, and bear a son, and shall name him Immanuel. He shall be living on curds and honey by the time he learns to reject the bad and choose the good. For before the child learns to reject the bad and choose the good, the land of those two kings whom you dread shall be deserted. (Isa 7:14-16) $)^{53}$

The Septuagint reads he parthenos for ha-almah; the Vulgate has virgo. The Gospel of Matthew then picks up this theme in 1:22-23 after the angel has appeared to Joseph and instructed him not to abandon his spouse Mary, because her child has been conceived through the Holy Spirit and is not the result of infidelity ${ }^{54}$ The child shall receive the name Jesus, and Matthew continues: "All this took place to fulfill what the Lord had said through the prophet: 'Behold, the virgin shall be with child and bear a

51. See the complete bibliography of the pamphlets written around the Isenbiehl controversy in Jung, Seelmann, 919-22.

52. Stuart A. Irvine, Isaiah, Ahaz, and the Syro-Ephraimitic Crisis (Atlanta, GA: Scholars Press, 1990).

53. Translations of biblical texts follow the New American Bible, Revised Edition (NABRE) (2011).

54. Mt 1:18-21: "Now this is how the birth of Jesus Christ came about. When his mother Mary was betrothed to Joseph, but before they lived together, she was found with child through the holy Spirit. / Joseph her husband, since he was a righteous man, yet unwilling to expose her to shame, decided to divorce her quietly. / Such was his intention when, behold, the angel of the Lord appeared to him in a dream and said, 'Joseph, son of David, do not be afraid to take Mary your wife into your home. For it is through the Holy Spirit that this child has been conceived in her. / She will bear a son and you are to name him Jesus, because he will save his people from their sins.'" 
son, and they shall name him Emmanuel,' which means 'God is with us'" (Mt 1:22-23).

The quotation from Isa 7:14 could be understood as the continuing speech of the angel proclaiming a direct relationship between the prophet's words and the events surrounding Jesus's birth. However, Christian tradition decided that Matthew had provided a divinely inspired commentary to the angel's words..$^{55}$ But the Christian tradition was not homogenous in its understanding of Isaiah and instead recognized two different (main) interpretations of the verse in question. One understood Isa 7:14 as direct prophecy about the birth of Jesus, while the other saw in it a contemporary image for the birth of Jesus and thus a typology. Isenbiehl rejected both and taught instead that Isa 7:14 had no connection to Jesus or to the New Testament. This was read as a direct assault on the authority of the Gospel of Matthew, which was, after all, a divinely inspired book that was believed to have had God as its primary author. If one took Isenbiehl literally, Matthew must have erred; but the Christian tradition claimed that the Bible, as God's inspired word, was infallible. However, Isenbiehl did not intend to attack Matthew's authority and, in fact, had defended the literary integrity of the entire book against the English exegete John Williams (1727-1798), who claimed that the first two chapters of Matthew had been written by someone else. ${ }^{56}$ In Mt 1:22, Isenbiehl claimed, the evangelist had not intended to interpret the prophet Isaiah, but only to compare two events from salvation history, the promulgation of the birth of Christ and the promulgation of divine help in a time of war and devastation. Both events had in common that two divine messengers, Isaiah and Gabriel, confirmed the authenticity of their mission by means of a miracle, namely the pregnancy of an unmarried woman. ${ }^{57}$ The main argument against Isenbiehl's thesis was that it contradicted both the consensus of the Church Fathers and Matthew's own words. Even the eminent historian of Lutheran theology Emmanuel Hirsch (1888-1972) conceded that orthodox Lutherans in the eighteenth century would have come to the same conclusion as Isenbiehl's Catholic critics. ${ }^{58}$

\section{ISENBIEHL'S INTERPRETATION IN DETAIL}

55. Reiser, Bibelkritik, 277-78. See the already concise overview of Richard Simon, Kritische Historie des Textes des Neuen Testamentes. Herausgegeben von Johann Salomo Semler (Halle: 1776), 438-43.

56. John Williams, A Free Enquiry into the Authenticity of the First and Second Chapters of St. Matthew's Gospel (London: 1771). Williams was a nonconformist English divine, and it seems that Isenbiehl was among the first to refute his claims with a monograph.

57. Isenbiehl, Neuer Versuch, 190-233.

58. At Reiser, Bibelkritik, 283. 
According to Isenbiehl, the Christian tradition acknowleged two interpretations of the verse. One saw it as a literal prophecy of the birth of Christ, the other as a typology of Christ. While the first one has more authority, since it is the opinion of the Fathers, the latter and more recent one had better arguments but was also "more confusing." ${ }^{59}$ Jerome (347-420) had mentioned the latter disapprovingly for the first time in his Isaiah commentary, but without condemning it as heretical.$^{60}$ Isenbiehl points to this fact and to the rediscovery of this reading by Grotius (1583-1645), who had made this interpretation almost universally accepted..$^{61}$ Exegetes in the eighteenth century, especially Catholics, increasingly accepted Grotius's interpretation, because it could be reconciled with the late medieval concept of a double literal meaning of Scripture. Such reconciliation means that Old Testament verses have a historical frame of reference, but they can and must be reconnected to Christ through the New Testament (examples are Hos 11:1/Mt 2:15; 2 Sam 7:14/ Hebr 1:5). This typological exegesis was also preferred by Calmet, who called it the "healthier interpretation." 62 Also, one of the most notable Catholic works of apologetics of the seventeenth century, Daniel Huet's (1630-1721) Demonstratio Evangelica (1679), defended a typological reading of Isa 7:14. This string of remarkable authorities was a crucial element of Isenbiehl's defense, because such a typological reading was just like his own interpretation, in contradiction to the consensus of the Fathers. ${ }^{63}$

Anthony Collins (1676-1729)—during the prime of deism ${ }^{64}$-began to dismiss even the typological reading of Isa 7: 14. He argued in 1724 that a prophecy could only be fulfilled if it was literal. A typological or allegorical prophecy would therefore be nonsensical. Since Isa 7:14 was about Isaiah's own son or the king's, it could not be fulfilled in Jesus Christ. Hermann Samuel Reimarus (1694-1768) later referred to Collins's hermeneutic principle in his explanation of the prophecies, and even Baron d'Holbach (1723-1789) relied on him in his Histoire critique de Jesus

59. Isenbiehl, Neuer Versuch, 17.

60. Reiser, Bibelkritik, 287. Jerome, Commentarius in Isaiam III 7, 714 (CCL 73/1, 105, linea 83).

61. Isenbiehl, Neuer Versuch, 20. On Grotius see Richard Simon, Historia Critica Commentatorum praecipuorum V. \& N.T. (Gosslar: 1713), 510-15; Simon, Histoire critique des principaux commentateurs du Nouveau Testament (Rotterdam: 1693), 807-8.

62. Augustin Calmet, Dissertationes ac disquisitiones: Excerptae ex commentario literali in omnes Veteris Testamenti libros, vol. 8 (Tyrnau: 1773), 83-117 (Dissertatio in illud Isaiae, at 87). On Calmet see Arnold Ages, "Voltaire, Calmet, and the Old Testament." Studies on Voltaire and the Eighteenth Century 41 (1966): 87-187. For Grotius's interpretation see H. J. M. Nellen, "Growing Tension between Church Doctrines and Critical Exegesis of the Old Testament," in The Old Testament: The History of Its Interpretation, vol. 2, ed. Magne Saebo (Göttingen: Vandenhoeck \& Ruprecht, 2008), 802-26, at 813.

63. Isenbiehl, Neuer Versuch, 132; Daniel Huet, Demonstratio evangelica (Paris: 3rd ed., 1690), propositio VII, n. 15, 351-69.

64. For Collins's methodology see Henning Graf Reventlow, The Authority of the Bible and the Rise of the Modern World (London: SCM, 1984), 354-83. 
Christ, which was condemned by the papacy in 1778 , the same year that the Isenbiehl scandal surfaced. Isenbiehl probably knew of Collins's principle and of d'Holbach, but if he did, he disguised this fact perfectly in his writings. ${ }^{65}$ The words in Isaiah in their "plain drift and design of the prophet, literally, obviously and primarily understood," refer to a young woman in the days of King Ahaz. The birth of her boy was a sign of hope and comfort for the people of God. A fulfillment of this prophecy over seven hundred years later could not have been an appropriate sign for Ahaz, thought Collins and Grotius-a view Isenbiehl adopted.$^{66}$

Isenbiehl consequently rejected the notion that a mystical meaning might lie beneath the literal meaning of Isa 7:14. As he saw it, the only two arguments that could be made in favor of such an interpretationfirst, that the term "virgin" fits better Mary, the Mother of God, than the wife of a prophet; and second, that the the son of the prophet was not named Immanuel-could not be defended. ${ }^{67}$ The first argument can be dismissed, reasoned Isenbiehl, because nothing in the expressed thoughts of Isaiah warrants that he wanted to express the notion of a miraculous virgin birth. ${ }^{68}$ Isenbiehl supported his argument with the second-century translations of Aquila of Sinope, Symmachus, and Theodotion, who have neanis instead of parthenos. Moreover, the definite article in ha-almah might indicate that the prophet was pointing to a young woman when he spoke the words of his prophecy, Isenbiehl argued..$^{69} \mathrm{He}$ rejected the second argument, because he found it incomprehensible that the Israelites would have kept the prophecy in the text, had it not been somehow fulfilled in

65. Anthony Collins, A Discourse of the Grounds and Reasons of the Christian Religion [1724] (London: 1741), 38. Cf. Reiser, Bibelkritik, 288-89. For a recent reprint of the main passages of Collins regarding prophecies see John Drury, Critics of the Bible 1724-1873 (Cambridge: Cambridge University Press, 1989), 21-45; and for a commentary see Hans W. Frei, The Eclipse of Biblical Narrative: A Study in Eighteenth and Nineteenth Century Hermeneutics (New Haven, CT: Yale University Press, 1974), 66-85.

66. Collins, A Discourse, 38. Collins, A Discourse, 39: “This prophecy [is] therefore not being fulfill'd in Jesus according to the literal, obvious, and primary sense of the words as they stand in Isaiah, it is supposed that this, like all the other prophesies cited by the Apostles, is fulfill'd in a secondary, or typical, or mystical, or allegorical sense." Cf. Isenbiehl, Neuer Versuch, 60 .

67. Isenbiehl, Neuer Versuch, 158.

68. Isenbiehl, Neuer Versuch, 159: "Ein wahrer Sinn ist ohne Zweifel der, welcher die Sache so vorstellet, wie sie ist, und wie der Prophet dieselbe im Gemüthe gehabt hat. Nun die Begriffe des Propheten können wir nicht anderst als aus seinen Ausdrücken erkennen. Ein wahrer Sinn ist also derjenige, welcher mit der eigenthümlichen Bedeutung derjenigen Wörter genau übereinstimmt, die Jesaias gebrauchet hat, um seine Gedanken auszudrücken. Allein der Gedanke von einer jungfräulichen Mutter ist gewiss nicht ausgedrücket. . . Er ist also nicht der wahre und noch weniger ein wahrer Sinn; er ist falsch."

69. Isenbiehl, Neuer Versuch, 45-54; Franz Sedlmeier, "Jesaja 7, 14. Überlegungen zu einem umstrittenen Vers und zu seiner Auslegungsgeschichte," in "Geboren aus der Jungfrau." Klarstellungen, ed. Anton Ziegenaus (Regensburg: Pustet, 2007), 3-43, at 27-28 shows that Isenbiehl simplifies here and that the Fathers who stated that almah means "also" virgin were right. 
the birth of a boy at the time of Ahaz, even if he had received a different name. ${ }^{70}$ After showing that the verse does not suggest a deeper mystical meaning, Isenbiehl expressed his conviction that God would primarily reveal himself in the literal meaning of a text: "Why cannot God talk in the way humans talk, when he talks to humans? This certainly would be appropriate. Did he not have the intention in his revelations that humans would understand him?"71

The Gospel of Matthew cannot be used against his interpretation, argued Isenbiehl, because Mt 1:22, "All this took place to fulfill what the Lord had said through the prophet," does not imply that Isa 7:14 is a prophecy about Christ. He then introduced a number of distinctions of what "fulfillment" can mean, relying on the work of his fellow Catholic exegete, the Jesuit Juan Maldonado (1533-1588), as well as on Augustine Calmet's literal commentary. ${ }^{72}$ Maldonado had analyzed what the verb could mean and arrived at four different meanings. First, it can mean a literal fulfillment; second, an allegorical fulfillment; third, a fulfillment can mean that something similar had happened; fourth, it could mean something that happened in the past that also occurs frequently in the present. Isenbiehl insisted that the third meaning must be the correct explanation of Mt 1: 22, although his two authorities never applied their findings to this particular verse ${ }^{73}$ Consequently, according to Isenbiehl, Matthew only wanted to point out a parallel between the births of the two boys. ${ }^{74}$ This does not mean that Isenbiehl had given up his belief in the virgin birth of Jesus Christ, but only that he prefered not to base it on a questionable verse from Isaiah, but rather on the teaching tradition of the Church. He reasoned that, therefore, his construal did not contradict the rule of the Council of Trent. ${ }^{75}$ Another argument in Isenbiehl's favor is his analysis of Mt 13:34-35 ("He spoke to them only in parables, to fulfill what had been said through the prophet"), where Jesus's way of speaking is connected to Ps 78:2. For Michaelis, this is Matthew's way of describing how Jesus used similar ways of preaching to the prophets of old.$^{76}$ Isenbiehl thought that, just as Matthew attempts to describe Jesus's preaching analogous to accounts in the Old Testament and not as fulfillment, so one also must understand Mt 1:22.

70. Isenbiehl, Neuer Versuch, 161.

71. Isenbiehl, Neuer Versuch, 35.

72. Augustin Calmet, Commentaire litteral sur tous les livres de l'Ancien et du Nouveau Testament (Paris: 1724-1726).

73. Isenbiehl, Neuer Versuch, 232-44.

74. The virgin birth cannot be proven through these verses anyway, Isenbiehl assures the reader. Isenbiehl, Neuer Versuch, 242.

75. Isenbiehl, Neuer Versuch, 132-35.

76. Isenbiehl, Neuer Versuch, 288; Michaelis, Deutsche Uebersetzung des Alten Testaments, vol. 6, Psalmen (Göttingen: 2nd ed., 1782), 185. 
Isenbiehl was aware that such a new reading requires the text to become "alien," since one has to overcome traditional hermeneutic presuppositions that find Jesus everywhere in the text, because one's mind is already occupied with his story. ${ }^{77}$ He furthermore questioned that a doctrinal truth (virgin birth) of Christianity should be built on the verses Isa 7:14 or Mt 1:22, because in the long history of their use to prove the fulfillment of the Old Testament in the New Covenant, this had not convinced the Jews, was never undisputed, and has never converted a substantial number of people. Isenbiehl therefore felt that enlightened Catholic theologians should abandon the use of these verses as dogmatic proofs, in order to avoid indirectly feeding into the arguments of the enemies of religion: ${ }^{78}$

What I say here is not imagination, but my own experience. I know a number of free-thinkers who would have been filled with zeal for religion, but who began to doubt when they heard the propositions ... and alleged arguments with which some try to prove the most important truths of faith.... Proofs, which do not stand the test of a thorough investigation, harm our cause more than that they are useful... Therefore I would not put our prophecy in the category of those from whom one can prove the fulfillment in the Christian Religion. ${ }^{79}$

\section{"HERMENEUTIC OF SUSPICION" OR "FRUITFUL CRITICISM"}

Isenbiehl rejected the exegesis of tradition, because he felt that not every exegetical commentary should be considered as truth of faith, even if it had been given by the Fathers, but that it must be subject to certain restrictions, for example, it had to have been accepted by all the Fathers. In the case of Isa 7:14, however, he disregarded the consensus of the Fathers, because none had interpreted the verse merely historically and, while he tried to conceal this fact by a number of sophisticated arguments, his opponents centered their criticism on this very fact. ${ }^{80}$ Isenbiehl's rejection of the Fathers was based on a hermeneutical principle that became during the eighteenth century a standard presupposition in exegesis, namely that the literal meaning of the text was primary and that, therefore, all mystical interpretations must be open to critical investigation.

77. Isenbiehl, Neuer Versuch, 3.

78. Isenbiehl, Neuer Versuch, 5.

79. Isenbiehl, Neuer Versuch, 5-6.

80. Ildephons Schwarz, Anleitung zur Kenntnis derjenigen Bücher, welche den Candidaten der Theologie ... wesentlich nothwendig und nützlich sind (Coburg: 1804), vol. 1, 170-71, stated that the church should have been grateful to Isenbiehl for his defense of the Gospel of Matthew and should not have overreacted, since he had never questioned a dogma of faith, just the proper exegesis of a verse. 
Isenbiehl argued that although some passages of the Bible contain double meanings, it would be "stupid" to suspect that all of Scripture was in need of such a double interpretation. Instead, because of the multitude of "very confused, and all too indeterminate, tasteless and superficial" 81 mystical interpretations, Isenbiehl came up with the rule that all (!) mystical readings must be viewed as "suspicious and allegedly false." ${ }^{12}$ Apart from this "hermeneutic of suspicion" about mystical interpretations, Isenbiehl's methodology rested on the presupposition that one should try to understand the Old Testament independently from the New Testament, and as a revelatory document and piece of literature in its own right.

If mystical interpretations misinterpreted a text, it is important to note what Isenbiehl understood by "false." A false meaning was for Isenbiehl that which the inspired author did not intend or which the Holy Spirit did not prescribe. Such false meanings, produced by allegorical or typological readings, might be useful for ascetcism and spiritual exercises but not for exegetes, he stated. Moreover, he made clear that one should not maintain the interpretation of the Fathers out of wrongful reverence or traditionalism, but take it seriously when they expressed that they only escaped to a mystical meaning when the literal meaning seemed impenetrable to them. If one took such statements of the Fathers literally, then exegetes could legitimately recover the literal meaning of biblical texts and one could shelve the mystical interpretations for such a verse ${ }^{83}$ It seems that Isenbiehl echoes Muratori here, and one can presume that he has read him. ${ }^{84}$

To Isenbiehl, a true meaning was that which "describes a thing as it is and as the prophet had it in mind." ${ }^{85}$ Since one can deduce the concepts

81. Isenbiehl, Neuer Versuch, 152.

82. Isenbiehl, Neuer Versuch, 153: "If we want to consider scripture without regard to its divine nature merely as a piece of human reason and creativity, we cannot deny that it can have a double meaning. ... This, however, is not an advantage which helps us to find traces of its divine origin, nor is it seldom that one would look for such cases in vain. The fables ... have under the appearance of the letters something hidden, which a theologian would call mystical meaning. As foolish as it would be to state a double meaning for all profane scriptures, it is equally foolish to state that all verses of Holy Scripture have a double meaning. Old and new writers have conceived such a mass of such mystical explanations that one can formulate this rule: every mystical meaning must look suspicious, and is allegedly false."

83. Isenbiehl, Neuer Versuch, 154.

84. Muratori, De ingeniorum moderatione in religionis negotio, lib. II, ch. 5290 , quoting Alphonsus de Castro, Adversus omnes haereses libri XIIII (Paris: 1541), 14: "There are people ... who are so affected [afficiuntur] by the writings of others, that when they vaguely realize that somebody deviates from the opinion of these writers in the smallest degree [digito transverso], they immediately call it heresy.... I therefore confess that I cannot withhold my anger [iracundia] whenever I see people addicted to the writings of men. . . . Such people want to regard the writings of men as if they were divine promulgations [divina oracula], and that one must receive them and show them the honor that one is only obliged to give to Holy Scripture."

85. Isenbiehl, Neuer Versuch, 159. 
of the prophet only through his expressions, a true meaning must be congruent with the idiosyncratic use of words one finds in Isaiah. However, the idea of a virginal mother cannot be found there; thus this concept cannot be part of the true meaning of the verse. "The two thoughts: she will conceive by losing her virginity and give birth; and she will conceive and give birth without losing her virginity cannot be conjoined in a proposition." ${ }^{86}$ Isenbiehl's opponents rejected this view and insisted that the New Testament with Christ's self-identification as the Son of God gave legitimacy to read Isaiah in the light of his incarnation and to give this verse a new meaning. For Isenbiehl, such an argument was flawed: with its help one could dismiss any intrinsic historical meaning of the Old Testament because a Christian would view the New Covenant as always superior ${ }^{87}$ Instead, Isenbiehl argued that the value of a meaning had to be derived from its clarity, its simplicity, and its congruence with the object and "natural judgement." 88 The clearest, simplest, and most natural explanation was therefore to assume that the Israelites would have purged the Isa 7:14 verse from Scripture, if contemporary readers had not believed that its prophecy had been fulfilled. ${ }^{99}$ To assume that all prophecies of the Old Testament pointed to Christ, as typological interpretation at this time usually assumed, was in Isenbiehl's view arbitrary: "If this were true, then all prophecies would be about Christ, and all writings of the prophets a permanent allegory. Who dares to say that? In Isaiah we do not find a word, not an expression ... from which one could suspect that it is a type for Christ." 90

Isenbiehl's enemies, especially Goldhagen, argued that Isenbiehl's "critical hermeneutic" of suspicion toward any mystical interpretation was heterodox. In a remarkable book that boldy defended Isenbiehl, most likely written by another biblical theologian, it was shown that criticism as the art of discernment must be at the core of exegetical work. ${ }^{91}$ The person cited to defend this statement was none other than the celebrated and universally admired Prince-Abbot of St. Blasien, Martin Gerbert (1720-1793), who was above any suspicion of heterodoxy. In his Exegetical Theology, Gerbert had developed seven rules of true and "fruitful" criticism. While the ability to discern whether a manuscript was true or

86. Isenbiehl, Neuer Versuch, 160.

87. Isenbiehl, Neuer Versuch, 160: "Der Werth des Sinnes wird nach dem Werthe des Gegenstandes geschätzet: und jene des neuen Bundes sind ohne Widerspruch schätzbarer, als etwas verlegenes aus dem alten. Aber nach dieser Schätzungsart könnte man bey einem geringen und niedrigen Gegenstand niemals einen vortrefflichen Sinn und Gedanken haben?"

88. Isenbiehl, Neuer Versuch, 160.

89. Isenbiehl, Neuer Versuch, 161.

90. Isenbiehl, Neuer Versuch, 162.

91. Anonymous, Katholische Betrachtungen über die zu Mainz, Heidelberg und Strassburg wider den Isenbiehlischen Versuch vom Emmanuel ausgebrachten Censuren (Frankfurt and Leipzig: 1778), 10-13. 
forged was part of a "therapeutic" criticism, hermeneutic criticism relied first, not only on the knowledge of the language of the text but on the use and patterns of the spoken language [viam ac rationem in omnia orationis schemata], as well as its allusions and hidden meanings [arcanas intentiones] and idioms. Second, a reader desiring to understand a text must know rhetoric in order to distinguish in a text true from false claims, allusions from descriptions, and to understand specific rhetorical patterns. Third, in order to judge not only singular words and idioms correctly, a reader must combine "natural and artificial logic" [logica tam naturalis ... artificialis concurrere debet]..$^{92}$ This means that the reader's mind must be actively present to discern the right meaning of words, sentences, and paragraphs, in order to draw the right conclusions. Fourth, the reader has to pay close attention not only to the historical circumstances of the text, but also to the coherence of the text. Fifth, the reader always has to have the intention [finis] of the author in front of him. This intention can be deduced from an entire longer text, or from texts that explain each other, or from those in which a doctrine is specifically entailed. This nexus between texts helps the reader find the "true meaning" of the text. Sixth, one has to explain the words of Scripture first and foremost literally and not figuratively, unless something absurd would follow. ${ }^{93}$ Thus far, Isenbiehl is presented as someone who followed the distinguished Martin Gerbert's advice in explaining Scripture. However, this could only be defended by omitting, as the anonymous defender did, the seventh rule of exegesis. This seventh rule states that when there seem to be multiple meanings, such a text must be read Christologically. Such an allegorical or typological meaning has apodactic force if it is found in Scripture and tradition. ${ }^{94}$ This last rule was the point where Isenbiehl deviated.

But how did the anonymous defender resolve the problem of Isenbiehl's deviation from the consensus of the Fathers? He agreed that an article of faith must be explicitly named in Holy Scripture or, if it is only alluded to in Scripture, has to be acknowledged as such by the Church. If an article of faith is not entailed in Scripture at all, then it must be contained in tradition, namely in the consensus of the Fathers of the first five centuries, for example., by demonstrating that they unanimously rejected the opposite as heretical. However, one also has to read the Fathers as "scholars, as ascetics, as homilists ... and in this regard they are private men [PrivatMänner], who explain obscure Scripture passages according to their own insights and according to the reasons that seemed most likely to them....

92. Martin Gerbert, Principia theologiae exegeticae (St. Blasien: 1757), 183. These rules are not contained, as the Katholische Betrachtungen claimed, in Gerbert's Apparatus ad eruditionem but in his exegetical theology. Another example of a positive view of criticial theology is Eusebius Amort, Demonstratio critica religionis catholicae nova, modesta, facilis (Venice: 1744).

93. Gerbert, Principia theologiae exegeticae, 183: "In sensu proprio scripturae verba sumenda, nec ad tropos recurrendum, nisi alias absurdum aliquod sequeretur."

94. Gerbert, Principia theologiae exegeticae, 183-84. 
In these matters, everyone is permitted to deviate from their opinions and to hold a different one ... until he is declared ... a heretic." ${ }^{\prime 95}$ Thus, for the defender, it was not a deviation from a truth of faith, since Isenbiehl did not question the virgin birth, but only deviated from the explanation of a scriptural passage. He went against the consensus of the Fathers, not with the intention of heresy, but of legitimate theological dissent.

\section{THE THEOLOGICAL WORLD AND ISENBIEHL'S BOOK}

The New Attempt was published at the end of October 1777 (although its cover states 1778) and was forbidden in Mainz in March 1778. By April it was forbidden in Speyer, Worms, and Fulda; Soon Trier, Cologne, Salzburg, Prague, Vienna, Würzburg, Passau, Chur, Paderborn, Hildesheim, and Regensburg followed suit. In Mainz the proscription decree was even promulgated from all pulpits of the archdiocese. ${ }^{96}$ While in Vienna the highest Court of the Empire, the Imperial Aulic Council, had already proscribed the book on 2 July 1778; the Archbishop of Mainz asked for further theological clarification and requested evaluations from the theology departments of Trier, Salzburg, Munster, and Heidelberg, as well as from the Sorbonne in Paris. The whole world disputed about his book while Isenbiehl remained silent.

As an example of the reports of the theology departments, which argued almost identically, I want to single out Strasbourg as typical. Strasbourg's report is also worthy of note because this theology department heavily emphasized a new argument against Isenbiehl, namely the argument from the perspective of Christian worship as a locus theologicus. The report of the Strasbourg department highlighted that the liturgy itself is ample proof that the Church understood the prophecy infallibly as a prophecy fulfilled in Christ. The Roman Missal as well as the Ambrosian and Mozarabian liturgies use the verse in the mystical sense, either allegorical or typological. The Strasbourg theologians also declared that the consensus of all theologians at all times would qualify the prophetic explanation as a truth of faith. ${ }^{97}$ Moreover, Isenbiehl's explanation, the Strasbourg theologians point out, was in substance derived from Socinian sources (specifically Socinus in his Lectiones Sacrae and Crell in his Opera

95. Katholische Betrachtungen, 15.

96. Weber, "Mainz," 222-23; Reichert, "Trier und seine theologische Fakultät," 283.

97. Judicium theologorum argentinensium de libro Germanico Vulgato: $J$. L. Isenbiehl, Neuer Versuch ... (Mainz: 1778), arg. III, 37. The theologians meant Benedict XIV, "De festis beate Mariae Virginis. Liber secundus. Caput primum," in Benedict XIV, Opera omnia, vol. 8, De sacrosancto missae sacrificio (Venice: 1767), 178. 
Exegetica), ${ }^{98}$ although they acknowledged that also some ancient rabbis had taught it. To Isenbiehl's argument that the church had never given the verse a definite interpretation, the Strasbourg theologians countered with Bossuet's response to Richard Simon that it was not wise of the church to decide undisputed truths, which are held in good faith by the faithful. ${ }^{99}$ The Strasbourg theologians also heavily criticized Isenbiehl for his disrespectful treatment of the Fathers. He had conceded that one could construct a proof for a doctrinal proposition or a certain biblical interpretation from the witness of the Fathers. If several Fathers declared that

the universal Church believed this or that teaching, then it would be as infallible as the whole Church is infallible. If they lived in the first centuries and witnessed that something was taught by the Apostles, it is as certain as if it was written in the canonical books of the New Covenant. ... Not a single Father of the Church states that his opinion is the meaning the entire Church embraces or the meaning the Apostles held. That our prophecy is about Jesus Christ is not even regarded as the belief of particular churches. Can one really make use of witnesses for proof, if they do not witness to anything at all ?100

The theologians of Strasbourg argued that such a view of tradition was minimalistic. Following this approach, no dogmatic proofs could be made at all. Moreover, they insisted that Isenbiehl's restrictions were arbitrary and contradicted the Council of Trent's declaration about the explanation and interpretation of Holy Scripture. The theologians regarded Isenbiehl's rejection of Irenaeus - who explicitly speaks about the apostles' belief in the prophecy as a philosophical reflection-as proof of Isenbiehl's sophistry. ${ }^{101}$ Likewise, Isenbiehl's assertion that Trent's rule for interpreting Scripture was not part of the deposit of faith but just a pastoral command was rejected, since it had been explicitly included in the profession of faith of Trent. Isenbiehl's attempt to cite Daniel Huet as an example of another theologian who contradicted the Fathers without magisterial repercussions was similarly unsuccessful with the Strasbourg theologians, because Huet had at least held a typological view of the prophecy..$^{102}$ For the theology department, the case was clear. Isenbiehl's minimalist historical interpretation of Isa 7:14 that excluded any Christological dimension, along with the insistence that the Evangelist Matthew

98. Judicium theologorum argentinensium, 72: "Substantiam ergo Systematis sui Auctor ex Socinianis hausit." Grotius is treated here as Socinian. Cf. Judicium theologorum argentinensium, 62-72.

99. Judicium theologorum argentinensium, 75. Cf. Joseph Gass, Strassburger Theologen im Aufklärungszeitalter, 1766-1790 (Strasbourg: 1917), $38-43$.

100. Isenbiehl, Neuer Versuch, 123-24.

101. Judicium theologorum argentinensium, 84-106.

102. Judicium theologorum argentinensium, 131, 135. Isenbiehl, Neuer Versuch, 139-40. 
was wrong, were heretical viewpoints. The Sorbonne came to an almost identical conclusion on 1 August 1778.

It is important to note that two theological worlds collided here. One allowed a certain amount of freedom of theological research, while the other regarded the patristic interpretation as a revealed truth of faith. Abbé Louis of Strasbourg, who in an article for Goldhagen's journal explained the verdict, proves this. Abbé Louis deemed Isenbiehl's doctrine to be heretical because it directly opposed what had always and everywhere been believed in the Catholic Church. It was a "catholic truth of faith" that Isaiah predicted in Isa 7:14 (1) the Messiah, who (2) is Christ, and that (3) Matthew recognized this. "This is so obviously [aperte] contained in Scripture and tradition that according to unanimous consensus [omnium consensu] it has to be regarded as revealed [revelatae]." 103 Isenbiehl's book was heretical because it denied these three claims. According to the Strasbourg faculty department, everyone who contradicts the unanimous consensus of the Fathers, contradicts tradition and is therefore a heretic [haereticum esse] ${ }^{104}$ When confronted with the question as to whether the department had judged Isenbiehl too harshly, Abbé Louis responded on 7 May 1778: ${ }^{105}$

The academics [in Germany] imagine that a teaching is only heretical if its opposite ... was explicitly defined by the church ... but this opinion is false. For a teaching to be heretical it is sufficient that the tradition of the church was always against it. It is not necessary for the Church to have defined the opposite. ${ }^{106}$

The problem with this statement was of course that the opinion Jerome reported from the fourth century was never rejected as heretical. Thus, Isenbiehl had communicated: "The Holy Fathers were not accustomed to anathematizing everyone who did not share their opinion. ... They excluded only those from their community who had argued against explicit revelation, true tradition." ${ }^{107}$ Louis, however, had a narrower understanding of tradition and was able to dismiss this argument because he embraced wholeheartedly what Charles du Plessis d'Argentré (16731740) already had stated in his Elementa Theologica (1702). According to this learned doctor of the Sorbonne and later bishop of Tulle, everything that was known through perpetual and universal tradition as being contained in Scripture, was of divine and Catholic faith and had the highest

103. "Kurzgefasste Erläuterung der Censur, welche die löbliche theologische Facultät zu Strassbyrg . . . über die drey vornehmsten Sätze des Isenbiehlschen Versuches . . g gefällt hat," Religionsjournal. Beylagen 1 (1778-24 July), 205-18, at 210.

104. Kurzgefasste Erläuterung der Censur," 216.

105. "Antwort welche der oft belobte Hr. Professor Louis zu Strasburg . . gegeben hat," Religionsjournal. Beylagen 1 (1778-29 August), 222-24.

106. "Antwort welche der oft belobte Hr. Professor Louis," 222-23.

107. Katholische Betrachtungen, 30 . 
claim to being defined doctrine. ${ }^{108}$ Also, the question whether it could be an article of faith that one had to understand a text this or that way was answered in this work. ${ }^{109}$ For this purpose, du Plessis d'Argentré differentiated between two kinds of texts. One kind was understandable by itself [per se apertus], the other through the perpetual or continous tradition of the Church, whereby the tradition that explained a text of the second category belongs to the deposit of divine faith. ${ }^{10}$

Isenbiehl's anonymous defender did, of course, cite Muratori and his view in defense of the German exegete, but it should be clear that two irreconcilable theologies clashed in this case. The charge of the theology departments that Isenbiehl would marginalize Mary with his exegesis was rejected with a reference to Muratori. According to the latter, Mary would despise it if mere "opinions" (e.g., the interpretation of Isa 7:14) were treated as if they were of divine origin. ${ }^{111}$ Louis and the theology faculties of Mainz, Heidelberg, Strasbourg, Paris, and Salzburg were not about to listen to Muratori, especially not when they were charged with a sin against charity in denouncing a book. ${ }^{112}$ They were equally unimpressed that in defense of Isenbiehl he even quoted Cornelius Jansen (1535-1638), who as the founding father of Jansenism was certainly above any suspicion of laxism, in defense of Isenbiehl. The bishop of Ypres had stated that from the words of the prophecy in Isaiah alone one could not conclude that the virgin would conceive as virgin and give birth as virgin, and that therefore, the verse was worthless for a dogmatic defence of the perpetual virginity of Mary. ${ }^{113}$ The Würzburg theologian Franz Oberthür (1745-1851), one of Germany's most ardent Catholic Enlighteners, nevertheless, defended Isenbiehl:

I have not found the least of what could be regarded as heresy.... It is not orthodoxy to believe a proposition because some hold it and declare: this is the opinion of the Church (communis theologorum)! Instead, one has to

108. Charles du Plessis d'Argentré, Elementa theologica, in quibus de autoritate ac pondere cujuslibet argumenti theologici ... disputatur. Postremo etiam accedit, cum de fide divina tum de summa Ecclesiae authoritate in proscribendis nominatim et damnandis perversis quibuscumque scriptis, tractatio (Paris: 1702), 329: "Respondeo: quaecunque in Scriptura sacra contineri, perpetua \& universali Ecclesiae Traditione constat, ea esse de fide divina simul \& catholica."

109. Du Plessis d'Argentré, Elementa theologica, 330-31: "An fidei divinae \& catholicae dogma esse possit, hunc vel illum Scripturae sacrae locum hoc vel illo sensu intelligendum esse; seu, an sit a Deo revelatum, quisnam sit sensus germanus singulorum Scripturae locorum, \& ubinam extet illa revelatio?"

110. Du Plessis d'Argentré, Elementa theologica, 331.

111. Katholische Betrachtungen, 24; for a classic rejection of Muratori's Marian theology see St. Alphonsus of Liguori, The Glories of Mary. (1750).

112. Katholische Betrachtungen, 8; Muratori, De ingeniorum moderatione in religionis negotio, lib. II, ch. 5. On Muratori see Paola Vismara, "Ludovico Muratori," in Ulrich L. Lehner and Jeffrey Burson, eds., Enlightenment in Catholic Europe.

113. Cornelius Jansen, Commentariorum in suam concordiam ac totam historiam evangelicam (Leuven: 1606), c. 8, 53-54. Cf. Katholische Betrachtungen, 23. 
prove with arguments that it is the opinion of the Church. To hold such a proposition is reasonable orthodoxy, and it is this, what the Church asks of every Catholic. Sit rationale obsequium vestrum. (Rom 12:1) ${ }^{114}$

Apart from a few anonymous theologians and some Catholic Enlighteners or Reformers, who were already suspected of schism or heresy (Ruatenstrauch, Oberthür, Hontheim, etc.), nobody came to a defense of Isenbiehl. His critics used this situation to portray the author as a freethinker and wanted the book condemned not just by a few German bishops but by the pope himself. The denunciation was sent to Rome, and the Holy Inquisition began a formal investigation of the New Attempt and its author.

\section{"IMPRISON THE AUTHOR AND BURN THE BOOK!"}

Isenbiehl had been arrested on 28 December 1777, and he remained for two months in the Cathedral prison in Mainz. He rejected all requests to explain his theses and to answer the charges of heresy, unless he would be released from prison in order to draft a response in peace and tranquility. Only after he finally recited the Creed in front of the Cathedral chapter was he allowed to leave the prison for an internment in the abbey of Eberbach, where he was imprisoned from February 1778. The abbot there treated Isenbiehl badly because he assumed this would amuse the elector. ${ }^{115}$ All attempts by Karl von Dalberg to get Isenbiehl acquitted or even released on a bail of 1,000 talers-an enormous sum-failed. After an unsuccessful attempt to escape the monastery, Isenbiehl was again imprisoned in Mainz until he finally recanted. ${ }^{116}$

Many historians have wondered why Isenbiehl published his book and whether he was really so naive as to expect no repercussions. One could have found the answer quite easily in the New Attempt. There the Mainz exegete states that he published the thoughts of his lectures

114. Magazin zum Gebrauch der Staaten- und Kirchengeschichte 8 (1783), 25-28, at 26.

115. Dom- und Diözesanarchiv Mainz: Bestand 12/1, Nr. 153; Haus-, Hof- und Staatsarchiv Wien, Mainzer Erzkanzler Archiv, Geistliche u. Kirchensachen 81, letter of F. Adolphus abbas, Eberbach to the Elector of 15 February 1778 (I thank Mr. Sascha Weber for bringing this letter to my attention). Helmut Mathy, "Isenbiehl, Johann Lorenz," in Neue Deutsche Biographie 10 (1974): 191-92; Brück, Die Mainzer theologische Fakultät, 58.

116. Isenbiehl did not want to escape to Utrecht, as his friend Dalberg suggested, although there were "plenty good Catholics and freedom." Dalberg to Oberthür on 18 August 1778, Universitätsbibliothek Würzburg, Nachlass Oberthür, Passivkorrespondenz, at Jung, Seelmann, 638. For the Dalberg-Isenbiehl relationship see Ferdinand Koeppel, "Karl von Dalbergs Wirken für das Hochstift Würzburg unter Franz Ludwig von Erthal," Zeitschrift für Bayerische Landesgeschichte 20 (1957): 253-98. 
because men of faith and learning (Hontheim, ${ }^{117}$ Rautenstrauch, Gertz, Michaelis) encouraged him to do so. Moreover, he insists on his academic and, especially, his Christian (!) freedom to make his opinions publiceven if they did, as he put it, "clash with contemporary school opinions, they are presented in the freedom which Christ has given us and which neither Church nor State can take away from us."118

The investigation by the Holy Inquisition in Rome seemed initially to take a good course. In order to judge the book fairly, Isenbiehl's New Attempt was translated into Latin and Italian. ${ }^{119}$ Then, however, the Franciscan censor Guiseppe Antonio Martinelli (1717-1788) judged the entire work [doctrina] to be downright heretical. A second report, probably by Michele di Petro (1747-1821), denied this qualification. Although the censors were required to consult prior decisions about the book issued by Catholic theology departments (e.g., the decisions of the departments of the Sorbonne-Paris, Heidelberg, and Mainz), they could not have considered the one university report that defended Isenbiehl (at least initially), issued on 21 April 1778 by the theology department of Salzburg, because it was filed in German-despite the fact that the original was of course in Latin. ${ }^{120}$ It seems that either some mysterious conspiracy or simple negligence successfully silenced the one voice that was favorable to the author. The consultors of the Roman Inquisition did not follow Martinelli and did not consider the entire teaching [doctrina] of Isenbiehl "heretical." Instead, they decided that only certain propositions were to be censored

117. Hontheim was ferociously attacked for his sympathy with Isenbiehl's book by his own bishop, as well as by the papal nuncio, and this ultimately led to his downfall. $\mathrm{He}$ defended himself by insisting that he had only received a part of the manuscript, and that he had relied on the unpublished review of Philipp Cordier (1716-1779), a Jesuit theologian in Trier, who had not identified any heresy in Isenbiehl's New Attempt. Cordier made clear that he disagreed with Isenbiehl, as one could see from his book Religio christiana ex prophetis antiquis demonstrata (Trier: 1775), 28-36, but he defended Isenbiehl against the charge of heresy. Cf. Reichert, "Trier und seine Theologische Fakultät," 292. Cf. Ulrich L. Lehner, "Johann Nikolaus von Hontheim and his Febronius," Church History and Religious Culture 88 (2008): 93-121.

118. Isenbiehl, Neuer Versuch, preface.

119. Dominik Burkard also points out that the consultors were unable to read Hebrew and therefore could not follow Isenbiehl's argumentation. Burkard, "Schwierigkeiten bei der Beschäftigung mit der päpstlichen Zensur im ausgehenden 18. Jahrhundert am Beispeil der Causa Isenbiehl," in Verbotene Bücher. Zur Geschichte des Index im 18. und 19. Jahrhundert, ed. Hubert Wolf (Paderborn: Schöningh, 2008), 311.

120. Burkard, "Schwierigkeiten," 312. This is remarkable since the original report of the Salzburg theology department was of course in Latin (of 21 April 1778). At the time of this writing, Burkard has not yet answered my e-mail question as to which report is entailed in the files of the Roman Inquisition (July 2011) - in his article he only speaks of "the" Salzburg report. The original (first) report is reprinted in Katholische Betrachtungen, 169-208. Moreover, it was signed by the dean of the department, Simpert Schwarzhueber, O.S.B., who himself was a renowned Mariologist and not in the least suspicious of heterodoxy or modernist leanings. However, on 10 September the department wrote a new, more thorough report, which now harmonized with the other, negative voices (Gass, Strassburger Theologen, 54). 
and rejected ten qualifications of the censors as too harsh or unfounded. ${ }^{121}$ Nevertheless, these were still considered "falsa," "temeraria," "perniciosa," and "haeresi proxima," but they were convinced that Isenbiehl's book was only conducive to heresy, not intrinsically heretical. Pope Pius VI (reign 1775-1799) affirmed this assessment in his brief Divina Christi Domini Voce on 20 September 1779 and condemned the possession or reading or dissemination of the book with the punishment of excommunication. According to the pope, it contained a poison [venenum] that could easily lead the reader to a complete irreverence toward the Fathers and to an interpretation of Scripture according to personal whim [spiritus privatus]. He explicitly invoked the Council of Trent's hermeneutical rule and complained that Isenbiehl, in his cleverness, did not feel the urge to surrender to tradition. ${ }^{122}$ It is remarkable that Divina Christi Domini Voce is the only magisterial teaching or exhortation regarding biblical exegesis between the Council of Trent and Pius IX's Syllabus of Errors (1864) that has been included in the Enchiridion Biblicum, the official collection of magisterial texts on the Bible. It reads,

A terrible insult to Catholics has been published. They have heard stated publicly that the prophecy concerning the divine Emanuel, sprung from a virgin, in no way, neither literally nor typologically, refers to the Mother of God's virginal begetting of him, which all the prophets announced. It has nothing to do with the true Immanuel, Christ the Lord. And this when St. Matthew testifies expressly that the remarkable prophecy was fulfilled in that wondrous mystery of religion. Yet it is claimed that the Holy Evangelist does not recall it as a fulfillment of the prophecy, but a mere passing mention or allusion. On hearing this, pious people have been horror-struck. Scripture and also tradition, as it has come down to us from the constant agreement of the Fathers, is being undermined with utter shamelessness. ... We, therefore, ... with the plenitude of apostolic power, condemn the said book ... as containing doctrine and statements that are respectively false, rash, scandalous, dangerous, erroneous and favoring heresy and heretics. It is our wish and decision that hereafter the said be forever considered condemned and disapproved of. ${ }^{123}$

121. The rejected qualifications included "piarum aurium offensivas," "simplicium seductivas," "Theologis et Patribus injuriosas," "contumeliosas," "periculosas," "de haeresi suspectas," "haeresique faventes," "praesertim vero Socianismo," "ipsumque sapientes," "erroneas," and "damnatisque alias ab Ecclesia persimiles, atque damnandas." Burkard, "Schwierigkeiten," 309.

122. Burkard, "Schwierigkeiten," 299-316.

123. The translation can be found in Pius VI, Brief "Divinia Christi Domini voce (1779), in The Church and the Bible: Official Documents of the Catholic Church, ed. Dennis Murphy (Staten Island, NY: St Pauls/Alba House, 2007), 36. For the Latin original see Enchiridion biblicum documenta ecclesiastica Sacram Scripturam spectantia (Naples/Rome: 4 th ed., 1965), 31-32. As usual in collections like the Enchiridion, the letter is substantially shortened, here by almost two-thirds. The entire text, so it seems, was only published in a Protestant journal, namely August Schlözer's Briefwechsel, vol. 6, issue 37 (1780): 346-51, and hitherto no one has really paid much attention to it. 
After such a universal condemnation Isenbiehl could no longer withhold his recantation if he did not want to be imprisoned for life. Thus, he submitted to the Holy See and signed his recantation, denouncing his own book on Christmas Day 1779; he was consequently released from prison on 30 December 1779, rehabilitated, and given the position of a canon in Amöneburg. However, because of some bureaucratic error, his book did not appear on the Index of Forbidden Books until 1783. There was no chance that he would ever be permitted to work as a professor again, and apart from a two-volume introduction to theology he produced in 1787, he never again took up his pen for academic purposes. ${ }^{124}$ The case of Isenbiehl shows that the Catholic Church did not agree with Isenbiehl's critical hermeneutical stance on Isa 7:14, which the father of modern liberal Protestant theology, Johann Salomo Semler (1725-1791) expressed thus: "Jesus is everything that he was and what he has done ... regardless of whether the verse in Isaiah is said about his birth or not." 125 It would be another forty years until another Catholic theologian, Peter Alois Gratz (1769-1849) of Tübingen, would cautiously build on Isenbiehl's insights, incorrectly believing that the times had changed. In 1821, he too lost his chair over this matter. ${ }^{126}$ It is an irony of history that today Isenbiehl's historical method has become the standard academic approach to Isa 7:14, although there is still some discussion as to whether the verse refers to the prophet's or the king's son. ${ }^{127}$

\section{MAGISTERIAL IMPLICATIONS}

The Isenbiehl controversy provides the historical context of why Catholic exegetes over the next generations became worried about emphasizing

124. Johann Lorenz Isenbiehl, De Rebus Divinis tractatus, 2 vols. (Mainz: 1787). These volumes are a patristic explanation of Holy Scripture. A review of Isenbiehl's De Rebus Divinis can be found in the Mainzer Monatsschrift für Geistliche Sachen 3 (1787): 404-7; see 408-16 for Isenbiehl's defense against a (different) critical reviewer. When his friend Gertz informed him in 1783 about events in the scholarly world, Isenbiehl answered sarcastically: "You want to entertain me with scholarly matters? You should have written about onions, garlic and soup herbs ... since I am now responsible for the economy of this chapter ... and no longer an author, a scholar, a Biblicist or reader of the Fathers, but a farmer, gardener and cook! Gosh, what a metamorphosis." At Weber, "Mainz," 227.

125. At Richard Simon, Kritische historie des Textes des Neuen Testamentes, 443n.

126. Peter Alois Gratz, Historisch-kritischer Kommentar über das Evangelium des Matthäus (Tübingen: 1821), 56. For Gratz the meaning of Isaiah's verse was first of all historical, but he conceded that it was at the same time also an unconscious prophecy about the future, unknown to the author. Thus, by some divine providence, unknown to the prophet, the utterance of Isaiah was also and even more completely fulfilled in Christ. Norbert Wolff, Peter Alois Gratz (1769-1849). Ein Theologe zwischen "falscher Aufklärung" und "Obscurantismus" (Trier: Paulinus-Verlag, 1998), 229, 246, missed that Gratz knew Isenbiehl's work.

127. Reiser, Bibelkritik, 319; Martin Rösel, "Die Jungfrauengeburt des endzeitlichen Immanuel," Jahrbuch für biblische Theologie 6 (1991): 135-51. 
the historical-literal reading of a text and rather left this approach to their Protestant peers. It also shows that the papacy did not reject historical criticism per se, as it was perceived by many, but rather a historical/literal approach that claimed to be the only legitimate approach to Scripture, in particular if such an approach was against the "consensus of the Fathers." "Consensus" was understood as the moral yet universal harmony of the Fathers in their interpretation of a certain verse and considered part of the universal belief of the church. ${ }^{128}$ The papal decision to censor Isenbiehl can only be regarded as a clear rejection of the historical-critical method as it was known and practiced by Johann Salomo Semler (1725-1791) or Johann August Ernesti (1707-1781), who both insisted that only the historical, grammatical sense should be regarded as the licit meaning of a text passage, and that the authority of the Fathers was hermeneutically inadmissible. ${ }^{129}$ Besides Gratz, a number of other Catholic exegetes fell victim to such policy, Johann Jahn of Vienna (1750-1816) being the most prominent one. Jahn, who was in the first third of the nineteenth century arguably the most prominent Catholic Old Testament scholar, faced in 1805 a similar choice as Isenbiehl, namely to publicly write and teach according to "common belief," but rejected it because he "could not consciously tell . . . a lie." 130 Like Isenbiehl he dismissed the Fathers as "fallible interpreters" and argued against the Augustinian Engelbert Klüpfel (1733-1811) that the diversity of opinions among the Fathers was much greater than usually conceded, and that no reference to their authority could ever replace historical-philological work. ${ }^{131}$ The censoring of theologians who saw the historical-critical approach as the only legitimate or at least supreme approach to Scripture intimidated Catholic biblical scholars, who understandably withdrew to "safe" research areas and left the field to their Protestant peers, with the result that Catholic exegesis began to become irrelevant for academic discourse. While Vatican I did not show much understanding for the relevance of independent historical exegesis, it understood that the Bible was a book of the church and that there was no way to adequately understand its content except through the church. ${ }^{132}$ Catholic exegesis was bound through the text of Dei Filius

128. Franz Vog1, Die heilige Schrift und ihre Interpretation durch die heiligen Väter der Kirche (Augsburg: 1836), 106-10; cf. Georg Michael Wittmann, Principia catholica de sacra Scriptura (Regensburg: 1793). On moral certainty see Sven Knebel, Wille, Würfel, und Wahrscheinlichkeit (Hamburg: Meiner, 2000).

129. Hermann Joseph Pottmeyer, "Die historisch-kritische Methode und die Erklärung zur Schriftauslegung in der dogmatischen Konstitution Dei Filius des I. Vatikanums," Annuarium Historiae Concilium 2 (1970): 87-111, at 98.

130. Johann Jahn, Nachträge zu seinen theologischen Werken (Tübingen: 1821), vii; cf. Jahn, Enchiridion hermeneuticae generalis (Vienna: 1812).

131. Pottmeyer, "Die historisch-kritische Methode," 100. Cf. Wendelin Rauch, Engelbert Klüpfel. Ein führender Theologe der Aufklärungszeit (Freiburg: 1922), 79-86, 149-55.

132. Pottmeyer, "Die historisch-kritische Methode," 110. Joseph Ratzinger, Traditionsbegriff, 47, at Pottmeyer, "Die historisch-kritische Methode": "dass, gleichwie es ein Wächteramt 
to the scriptural meaning the church has held and holds. Yet, until 1943's Divino Afflante Spiritu, Catholic theologians would have to fear the possibility of being dismissed from teaching positions or being denied the permission to publish if they went beyond these boundaries of research and established historical interpretations independent from tradition. ${ }^{133}$

The Isenbiehl episode was also a step into the direction of a central theological magisterium under the guidance of the popes. The Council of Trent had promulgated a reform decree about scriptural interpretation that aimed at restricting abuse and libertinist interpretation. It maintained that that the meaning of Scripture as it was held by the church (tradition) was normative and that it was the duty of the church, bishops, and theologians (doctores et magistri), to ensure (iudicare) that exegesis did not contradict it (contra sensum ecclesiae). In the aftermath of Trent, however, tradition seems to have become subservient to the magisterium. ${ }^{134}$ On the eve of Vatican I, for some Catholic theologians of the so-called Roman school (e.g., Perrone), which heavily influenced Vatican I, the magisterium is even identified with tradition. ${ }^{135}$ Vatican I reiterated Trent's formulation in the dogmatic constitution Dei Filius (1870) but turned it positively so that it stated that the true meaning of sacred Scripture was the one the church held and holds (tenuit ac tenet) and that the church alone had jurisdiction to judge about the right scriptural interpretation. Church, however, no longer included ordinaries and theologians, ${ }^{136}$ as it had at Trent, but meant the central magisterium of the pope, and iudicare

der Kirche und ihrer geistbegabten Zeugenschaft gibt, so auch ein Wächteramt der Exegese besteht, die den Literalsinn erforscht und so aller Gnosis entgegen die Bindung an die Sarx des Logos hütet. Insofern gibt es dann so etwas wie eine Eigenständigkeit der Schrift als eines selbständigen und in vieler Hinsicht durchaus eindeutigen Masstabes gegenüber dem kirchlichen Lehramt."

133. As was the case in Germany with Joseph Schnitzer in 1908. See Manfred Weitlauff, Der "Fall" des Augsburger Diözesanpriesters und Münchener Theologieprofessors Joseph Schnitzer (1859-1939) (Augsburg: Verl. des Vereins für Augsburger Bistumsgeschichte, 2011). Henning Graf Reventlow, "Katholische Exegese des Alten Testamentes zwischen den Vatikanischen Konzilien," in Die katholisch-theologischen Disziplinen in Deutschland, 1870-1962, ed. Hubert Wolf (Paderborn: Schöningh, 1999), 15-39, at 22: "Noch 1938 war die Situation offenbar unverändert. Überall ist von seiten der Exegeten das Bemühen zu spüren, in dem Netz der Direktiven Schlupflöcher zu finden, die eine, wenn auch eingeschränkte Bewegungsfreiheit erlauben."

134. Hans Kümmeringer, "Es ist Sache der Kirche, iudicare de vero sensu et interpretatione scripturarum sanctarum. Zum Verständnis dieses Satzes auf dem Tridentinum und Vaticanum I," Theologische Quartalschrift 149 (1969): 282-96. This article is the text of a seminar paper written under the direction of Joseph Ratzinger, who recommended it for publication (see Kümmeringer, "Es ist Sache der Kirche," 282).

135. Walter Kasper, Die Lehre von der Tradition in der Römischen Schule (Freiburg: Herder, 1962), 179-81.

136. For the wider context of this important development see Klaus Unterburger, Vom Lehramt der Theologen zum Lehramt der Päpste? Pius XI., die Apostolische Konstitution "Deus scientiarum Dominus" und die Reform der Universitätstheologie (Freiburg im Breisgau: Herder, 2010). 
dogmatic decision making. ${ }^{137}$ Consequently, critics saw in the latter the end of "autonomous scriptural scholarship." 138 However one interprets the development from Trent to Vatican I, with the censoring of Isenbiehl, the papacy entered the stage of modern exegetical controversy; it took the stance that scriptural interpretation needs the Fathers and tradition, rejected the possibility of an autonomous historical-critical approach, and claimed the right to have the decisive say in defining the boundaries of exegesis. ${ }^{139}$

Catholic exegesis did not recover from the consequent narrowing of academic freedom until the eve of Vatican II, when theologians began to push open the door that Divino Afflante Spiritu (1943) had cautiously ${ }^{140}$ opened for historical criticism, turning it into a "floodgate."141 This new approach to Scripture was deeply attractive, also for the young Joseph Ratzinger during his studies of theology in Freising after World War II: "The candid questions from the perspectives of the liberal-historical method created a new directness in the approach to Sacred Scripture and opened up dimensions of the text that were no longer perceived by the all-too-predetermined dogmatic reading. The Bible spoke to us with new immediacy and freshness." Yet, he realized that this frankness could lead to a "flattening" of the Bible, which had to be "compensated for by obedience to dogma. A characteristic fruitfulness came from the balance between liberalism and dogma. ${ }^{142}$ It is this characteristic fruitfulness, so it seems, that Catholic theologians aim to recover by rejecting some of the positivist presuppositions of the historical-critical method and rediscovering tradition as an interpretive key to Scripture in what they call "theological interpretation." ${ }^{143}$ Pope Benedict XVI, well aware of Isenbiehl

137. Kümmeringer, "Es ist Sache der Kirche," 294-96; Pottmeyer, "Die historisch-kritische Methode."

138. Reventlow, "Katholische Exegese des Alten Testamentes zwischen den Vatikanischen Konzilien," 18.

139. The encyclical Providentissimus Deus (1893) recovered more freedom for the exegete and made some concessions to a historical-critical approach to Scripture, but most of them were withdrawn or relativized during the modernist crisis and in Spiritus Paraclitus (1920). Only Divino Afflante Spiritu (1943) opened Catholic theology to historical-critical methodology and more importantly to the hitherto rejected Formgeschichte. Hans-Josef Klauck, "Die katholische neutestmentliche Exegese zwischen Vatikanum I und Vatikanum II," in Die katholisch-theologischen Disziplinen in Deutschland, 1870-1962, ed. Hubert Wolf (Paderborn: Schöningh, 1999), 39-71.

140. Robert B. Robinson, Roman Catholic Exegesis since Divino Afflante Spiritu: Hermeneutical Implications (Atlanta, GA: Scholars Press, 1988).

141. H. J. Klauck, "Die katholische neutestmentliche Exegese." The image used here is Klauck's.

142. Joseph Ratzinger, Milestones: Memoirs, 1927-1977 (San Francisco: Ignatius Press, 1998), 52-53.

143. See especially Henri de Lubac, Medieval Exegesis: The Four Senses of Scripture [Exégèse médiévale, 1954-64], 3 vols. (Grand Rapids: Eerdmans, 1998-2009); Joseph Ratzinger, "Schriftauslegung im Widerstreit. Zur Frage nach Grundlagen und Weg der Exegese heute," 
and his approach, believes that historical-critical exegesis cannot provide a convincing interpretation of the prophet's words in Isa 7:14 and that a Christological reading is the only valid one. ${ }^{144}$ Marius Reiser, on whom the pope relies, however, does not share such a narrow interpretation but instead embraces the modern view that interprets the verse as a sign of hope for Ahaz's contemporaries, but states that the verse has an additional (mitgemeint) prophetic meaning due to its oracular character. $\mathrm{He}$ seems to embody the combination of "liberalism and dogma" mentioned above when he suggests, "The prophet's prediction is like a miraculously formed keyhole, into which the key of Christ fits perfectly." 145

in Idem, Schriftauslegung im Widerstreit (Freiburg: Herder, 1989), 15-44; Idem, Jesus von Nazareth, 3 vols. (Freiburg: Herder, 2006-2012).

144. Joseph Ratzinger/Pope Benedict XVI, Jesus of Nazareth. The Infancy Narratives (New York: Image, 2012), 48: "So the sign would need to be sought and identified within the historical context in which it was announced by the prophet. Exegesis has therefore searched meticously, using all the resources of historical scholarship, for a contemporary interpretation-and it has failed." See page 51 for a reference to Reiser, whom the pope quoted frequently in his Jesus books. For critical, yet overall sympathetic remarks about the pope's treatment of the infancy stories by the German exegete Thomas Söding, see http:// www.ruhr-uni-bochum.de/imperia/md/content/nt/aktuelles/papstbuchbd3/jesus_von_ nazareth_m_nchen.pdf (retrieved 18 December 2012).

145. Reiser, Bibelkritik, 328. 


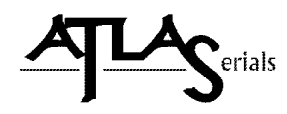

Copyright and Use:

As an ATLAS user, you may print, download, or send articles for individual use according to fair use as defined by U.S. and international copyright law and as otherwise authorized under your respective ATLAS subscriber agreement.

No content may be copied or emailed to multiple sites or publicly posted without the copyright holder(s)' express written permission. Any use, decompiling, reproduction, or distribution of this journal in excess of fair use provisions may be a violation of copyright law.

This journal is made available to you through the ATLAS collection with permission from the copyright holder(s). The copyright holder for an entire issue of a journal typically is the journal owner, who also may own the copyright in each article. However, for certain articles, the author of the article may maintain the copyright in the article. Please contact the copyright holder(s) to request permission to use an article or specific work for any use not covered by the fair use provisions of the copyright laws or covered by your respective ATLAS subscriber agreement. For information regarding the copyright holder(s), please refer to the copyright information in the journal, if available, or contact ATLA to request contact information for the copyright holder(s).

About ATLAS:

The ATLA Serials (ATLAS $®$ ) collection contains electronic versions of previously published religion and theology journals reproduced with permission. The ATLAS collection is owned and managed by the American Theological Library Association (ATLA) and received initial funding from Lilly Endowment Inc.

The design and final form of this electronic document is the property of the American Theological Library Association. 